\title{
SEIS POEMAS
}

\author{
Angelina Muñiz-Huberman
}

\section{Pasos}

Pasos por el suelo de trilladas hojas

Huellas desperdigadas sobre huellas desperdigadas

Donde pongo los pies otros pies y otros y otros

Sinfín de pisadas

Nadie se agachó a recogerlas

ni siquiera en una antología.

\section{JACARANDA ABATIDA}

Sé que llegará el día

en que se arrancará el espacio

de la jacaranda que tantos años

he contemplado desde el

cristal de mi ventana.

Sé que llegará. 